DOI: $10.32703 / 2415-7422-2019-9-1(14)-99-108$

UDC 329:352.07:364.467

Kislov Denis

Institute of Journalism, Cinema and Television of the Kyiv International University 49, Lvivska St., Kyiv, Ukraine, 03179

e-mail: kislov.denisv@gmail.com

https://orcid.org/0000-0002-9112-9832

\title{
Establishment of scientific research in communication studies in the 1920s - 1930s
}

Abstract. The article discusses and analyzes the role assessment and communication significance in state control systems in works and prominent representatives' statements of political thought from antiquity to the beginning of the twentieth century in accordance with the understanding of this phenomenon essence in the considered historical epochs. It is shown that from the history of political thought, although some well-founded concepts of the relationship between the authorities and the population of the thinkers of ancient China, India, and antiquity are known, they require more detailed and systematic understanding. The influence of the managerial and communicative ideas of Confucius, Plato and Aristotle on the subsequent works of Caesar, Cicero, the thinkers of the Middle Ages, the Renaissance and the Enlightenment are consistently discussed. A comparative analysis of individual views on the relationship between the state of public administration and communication of theologians and scientists of the XIII-XVIII centuries was conducted: F. Aquinas, F. Petrarch, L. Bruni, N. Machiavelli, M. Luther, T. More, T. Campanella, J. Boden, G. Grotius, J. Locke, T. Hobbes. Particular attention is paid to the ideas of S. Montesquieu, I. Kant, and G.-V.-F. Hegel as the founders of the scientific discourse around the problems of war and peace, the effectiveness of government and relations with the subjects of this management, with the people. In particular, the developments of the Chicago school in the United States and the Institute for Social Research in Germany, which laid the theoretical foundation for the beginning of the formation of information and communication theories that created the basis of the modern stage of communication development in the late twentieth century - early twenty-first century. Research and analysis in the work of the first historical ideas and theoretical concepts of the role, communication place and importance in public administration systems, advanced for 2500 years by a galaxy of eminent thinkers of the past, allows to rethink the sources of conceptual ideas of communicology put forward in the 20th century and approach the objective assessment of the perspective the role of the communication component of the humanity civilizational development in the twenty-first century. 
Keywords: history of science; history of communication studies; communication studies; communication; communicativeness; communication theory

\section{Introduction}

Modern scientific discourse on the definitions of the essence and nature of communication and communication studies, their genesis in the political, state and economic domains is exacerbating and becoming increasingly principle-guided. Such a situation requires a diverse and versatile coverage of the real picture of preconditions and development of theoretical works on communication studies in terms of their historical evolution. The understanding of these development processes should be based on contemporary views of the essence and cause-and-effect development sequence of theoretical thought in this branch of knowledge in the 20th century.

Theoretical issues of the development of social communications are discussed in research works of such Ukrainian scholars as V. Bebik, O. Zernetskaya, V. Ivanov, A. Konovets, G. Pocheptsov, V. Rizun, E. Romanenko, and A. Kholod. Concepts for communication studies and communicology were developed by such prominent scholars and thinkers as J. Baudrillard, N. Wiener, P. Lazarsfeld, H. Lasswell, N. Luhmann, B. Westley, C. Shannon, W. Schramm, R. Jacobson, and others. The history of communication studies in the first half of the 20th century is reviewed in the works of E. Wartella, O. Hnatiuk, J. Delia, E. Dennis, E. Rogers, M. Sproule, and C. Czitrom. However, national science has paid insufficient attention to this subject.

\section{Research methods}

The main purpose of this publication is to present the historical picture of the first period of theoretical works developing the comprehension of communication as a political and social phenomenon of the 1920s and 1930s.

The use of methods of bibliographic and source study analysis contributed to the search and systematization of primary information, and the use of the system method allowed to investigate comprehensively the state and development prospects establishment of scientific research in communication studies in the 1920s-1930s.

\section{Results and discussion}

After the radical changes in technical means of transport (river, sea, land transport, transportation routes) in the late 18th century, especially in England, understanding, and knowledge of communication processes was gradually becoming a necessity for the organization of collective work. It spurred scientific thought to explain the phenomenon of communication that occurs in public life and governance in other European countries. Favorable preconditions emerged for analysis and theoretical explanation of communication processes, and those preconditions are reflected in the ideas and statements of a number of researchers of that time up to the end of the nineteenth century, including A. Comte, A. Saint-Simon, H. Spencer, C. Darwin, K. Schapp, and others. With the advent and spread of technical means of 
communication - telegraph, telephone, radio - in the 19th and early 20th centuries, the communication and information transmission practice required theoretical comprehension of these processes from political and socioeconomic angles. The dominant doctrines of that time, including the popular Marxism, failed to provide intelligible scientific explanations of the new phenomena of practical communication. The consequences of social cataclysms and the First World War accelerated and intensified the research efforts in this field.

Scientific discourse is currently continuing on the dating and chronology of the communication studies history. The establishment of communication studies is sometimes dated back to the 1950's (Shalina, 2016). However, that starting point actually corresponds to the third, rather than the first historical period, when communication studies shaped up as a separate branch of research. Some authors associate the study of issues of political and managerial communication with research works in the field of propaganda during the First World War, revolutionary events and civil wars of 1914-1922. But in those years, there appeared only isolated works on methodologies of military propaganda, which can only be regarded as a preamble for future systematic studies of social communications. The century-old development path of the science that studies communication can by convention be divided into several periods, each of which is characterized by new significant achievements and transformations. There are arguably six evolutionary stages in the genesis of communication studies. In fact, the first period of research in the field of communication should be attributed to the time from the turn of the 1920s through the turn of the 1940s. Those research attempts were based on the knowledge and understanding of the communication between authorities and people, and among individuals, from the time of emergence and establishment of statehood in Ancient China and Ancient Greece as reflected in works of many outstanding thinkers of the past, from Confucius, Plato and Aristotle and up to authors of the early 20th century. These problems attracted the attention of leading sociologists and politicians of that time.

It was at the turn of the 1920s that basic concepts of communication science started to form up, including in its applied branches. Since then, mankind has gone a long way from the first ideas and concepts concerning social communication, its significance and role in the social, managerial and technological aspects to a set of sciences studying the application specifics of various communication channels, including the Internet and the problem of influence of media (network) communications on the global development of our civilization. However, many of the basic ideas of communication studies that have been put forward earlier sparkle today a broad and heated scientific debate. For this reason, it is important to turn to the outset of systematic efforts and publication of the first theoretical works in this field of knowledge.

The terminology of communication studies is yet to be established. Contemporary sources define communication studies as a science that studies the humanitarian aspects of communication, development of information systems and 
tools, and the nature, forms, and results of their impact on society. In scientific practice, there are some related terms: communication studies, communication theory and media-logy (Fedorov, 2010). This definition of communication studies can be taken as the basis for the correlation and fixation of all periods of formation and development of information and communication research in the 20th - 21th centuries.

The kickstart to the study of the role of communications in social and political processes came from works of prominent sociologist M. Weber. In 1919, his book "Politics as a Vocation and Profession" was released, in which he discusses three types of legitimate public authority in power (rational, charismatic and legal), which has the monopoly on violence (Veber, 1990). Studies by this author in the field of rational public relations, which he defended in debates with classical Marxism from 1905, had a significant impact on researchers - philosophers and sociologists supporters of the "critical theory." Theoretical search for alternative concepts began. The centers of research in the influence of communication on the behavior of the masses in crucial situations and situations of conflict became Chicago (USA), Frankfurt am Main (Germany) and Petrograd (Russia).

The ideas of M. Weber also had a definite influence on Russian-American sociologist P. Sorokin. In his fundamental works of that time, he most clearly showed the understanding of the role of communication in the development of revolutionary hostilities and in state governance practice, where the communication component linked the causes and subsequent actions of the revolutionary masses. The twovolume "System of Sociology" book was released in 1920 in Petrograd, the reason he was expelled from the post-revolutionary Russia in 1922. "Sociology of the Revolution" published in 1925 and "Social Mobility" in 1927 were released in the United States during his first emigration years (Sorokin, 1992). P. Sorokin had analyzed 1622 social crises and revolutions from 600 BC until 1925 and in the 1930s began to study the changes in the reaction of people in situations of social cataclysms, the polarization of their way of thinking and social behavior, interpersonal and intergroup communications.

The first decades of the 20th century in Western communication studies were marked by the activity of the Chicago school associated with the bloom of the empirical stage of research in American sociology. The founder of the school, R. Park, his colleagues N. Anderson, E. Burgess, R. McKenzie and other scholars focused on problems related to the role of communication in social ecology and in the processes that deepen and exacerbate social inequality and form a special urban "spiritual atmosphere" of communication. The influence of this school in the scientific world persisted until the Second World War. The theoretical aspect progressed at an especially fast pace, trying to find and identify some special mass media properties that make an actual influence on the thinking, behavior, and intentions of people. This period of time also coincided with the works of the US researchers in communication studies, W. Lippmann and H. Lasswell, who fulfilled a social order at the University of Chicago, studying the effectiveness of propaganda and the influence of mass communication systems (media) on the mindsets, habits 
and relationships of people among themselves and with the authorities. In 1927, H. Lasswell's book titled "Propaganda Technique in the World War" was published. The book discussed methods of propaganda work as a necessary tool for the government to form the needed public opinion. In the 1930s, he introduced the notion of "mass communications" into research practice. H. Lasswell compared the impact of the mass media and communications with the effect of a "subcutaneous needle" or "magic bullet," independent of the characteristics of a particular individual. This prompted certain power circles to use mass communications to manipulate people's behavior without limits. This mistake had been finally overcome many years later (in the 1970s), but up to now, it sometimes begins to dominate in certain circles of media tycoons and oligarchs who own television channels.

The propaganda experience of the First World War period was also in focus of study in the Weimar Republic in the 1920s and the early 1930s, where there was a group of scholars engaged in propaganda studies in 1922. On the basis of this group, the Institute for Social Research affiliated with the Johann Wolfgang Goethe University in Frankfurt am Main was founded in 1923. The organizational and research leaders of the Institute were philosopher M. Horkheimer, sociologist and cultural scientist T. Adorno and economist F. Pollock. From 1930, M. Horkheimer was gradually acquiring the management functions in the Institute and finally became its head in 1931. In the same year, the activities of this Institute were expanded to the Netherlands, where the archival department was established, and to Switzerland, where its branch was opened in Geneva.

Those who cooperated with the Institute of Social Research and its branch included many, known in Germany and the rest of Europe, philosophers, sociologists and economists of Marxist orientation, who, however, were very critical of certain concepts of this doctrine and sought to update it and re-think it theoretically in terms of social relations, the role of the state and its communications with the masses, influence on culture, etc. Their attempts to compensate for what Marxism missed the understanding of the role of information and communication in the socioeconomic life, led to the ultimate formation of the basic concepts of communication studies, enriched by some ideas of M. Weber, G. Hegel, I. Kant, S. Freud and other authors, as well as empirical propaganda data collected by the Institute for Social Research.

Having sensed the threat of Nazism at an early stage, the staff of the Institute began to relocate their activities out of Germany in the early 1930s. Before Hitler came to power, M. Horkheimer emigrated to the United States for ideological and national reasons, followed by the majority of the research staff by 1933. At the turn of the 1940s, a colony of immigrants from Europe, mostly German researchers, emerged in a small town on the west coast of the USA, between Los Angeles, the ocean and Hollywood. They united around the Institute for Social Research, whose director remained to be M. Horkheimer even in immigration, and continued to develop a research school at the University of Columbia, which is referred to in the 
history of research as the Frankfurt School in the United States, although its members did not use this name for themselves (Kuznetsov, 2011; Elizabeth C. Hanson, 2017).

On the whole, the activities of communication researchers of the Chicago and Frankfurt schools, as well as works of P. Sorokin and P. Lazarsfeld, and some other sociologists laid the theoretical foundation for the forthcoming formation of information and communication theories that created the basis for the present development phase of communication studies and communicology. The past lagging behind of Marxist theories in realizing the role and place of communication in public relations and the significance of the interaction between the authorities in power and the masses was overcome.

In the period between the two world wars, numerous private research efforts of various researchers in different fields of knowledge (mathematics, linguistics, semiotics, psychology) contributed to the future development of communication studies. More and more researchers from different countries became involved in work on communication problems. In the middle of the 1930s, the research heritage of the Chicago school was revisited. Based on a profound analysis of the propaganda role, methods and techniques, ways of social development and governance, H. Lasswell laid the foundation for a new research direction in communication studies between 1936 and 1940 known as structural and functional, which provided the theoretical basis for one of the modern concepts of communication. But competing research schools began to put forward alternative concepts. At the turn of the 1940s, various approaches appeared, introducing different understandings of the communication phenomenon in human societies and technical systems for decades to come. Researchers in various fields of knowledge still fundamentally differently interpret the notion of communication (Kislov, 2012). This controversy remains open as yet. But in response to that challenge, all the competing research groups worked out the most correct research methods for studying the activities of the media and mass communications (Lasswell, 1942). This methodological experience still remains valuable and in demand.

From 1937, the Rockefeller Foundation generously funded a large research project on the radio as a mass medium. Many scholars who had immigrated from Germany and Austria to the USA participated in that project. Among the most notable were P. Lazarsfeld, who headed the Bureau of Applied Social Research at Columbia University in 1933-1940 and T. Adorno, who also worked there. They studied the impact of the media and mass communications on the population, in particular, during election campaigns. P. Lazarsfeld came to the realization that communication media only partially affected voters' choice, and began to develop his own communication model.

At the beginning of the 1940s, in the face of military confrontations, a new level of mobilization propaganda was required and the efforts to study mass communication processes especially intensified. It was necessary to find practical methods for analyzing communication processes. At that time, the direction of scientific modeling of mass communications developed and established, and one of 
the most proponent representatives of that direction was again $\mathrm{H}$. Lasswell. He was one of the speakers at the permanently held seminars on mass communications in 1939-1940, where he outlined approaches to the model vision of mass communication process (Gnatyuk, 2004). H. Lasswell was the founder of the socalled "quantitative method of content analysis," within the framework of which he proposed a classical linear model of communication-based on the first model proposed by Aristotle offering the speech formula made up of three constituent elements: "the speaker," "the subject of the speech" and "the person to whom he addresses" (Aristotel, 2000): According to H. Lasswell, the content should be concretized using the formula: "Who? What is spoken about? What channel is used? To whom is the speech addressed? What is the effect of information transmission? This formula has become especially valuable for the development of appropriate research methods in the further analysis of communication processes. The theoretical and methodological significance of H. Lasswell's concept manifested itself in the fact that in this formula he identified five key elements of the exchange communication process: the communicator, message, transmission channel, recipient (audience) and effect (effectiveness, success of the process). The latter component itself raised questions the answers to which came later in the subsequent periods of the development history of communication studies from new breakthrough ideas and theories generated under the pressure of the Second World War.

\section{Conclusions}

The study and analysis of the first ideas and theoretical concepts of the role, place and importance of communication in socioeconomic systems, put forth in the period between the turn of the 1920s and the turn of the 1940s, allows us to rethink the sources of the basic conceptual premises of communication studies and come close to the objective assessment of the prospective role of the communication component in the development of human civilization in the 21 st century.

The scientific understanding of the significance of communication for the development of our civilization came only after the advent and sufficient spread of mass communication technologies and media from the second quarter of the 20th century. The outset of the comprehension of the communication phenomenon is rooted in a huge but scattered experience and numerous promising research ideas and products. The causes of the intensive research efforts were specific practical tasks, such as, for example, the need to have a more effective media impact on the public.

A major factor that fueled the research effort in this field was the significant financial support the researchers received at that time from special public and private funds in the United States. This fostered the concentration of best brains and holders of advanced scientific views of the time in this field. At the same time, favorable conditions were created for free self-development and competition of innovative ideas and research products, formation of unique informal research schools. Thus, additional conditions were created for successful work in the new areas of research, 
including communication studies where a solid foundation was laid for potential theoretical and technological achievements in the decades ahead.

\section{References}

Aristotel, (2000). Ritorika. Poetika [Rhetoric. Poetics]. Moscow [in Russian].

Fedorov, A. V. (2010). Slovar terminov po mediaobrazovaniyu, mediapedagogike, media-gramotnosti, mediakompetentnosti [Glossary of terms on media education, media pedagogy, media literacy, media competence]. Publishing House Taganrog State Pedagogical Institute, Taganrog [in Russian].

Gnatyuk, O. L. (2004). Iz istorii amerikanskoy kommunikologii i kommunikativistiki: Garold Lassuell (1902-1978) [From the history of American Communicology and Communicative Studies: Harold Lasswell (1902-1978)] / Aktualnyye problemy teorii kommunikatsii. Sankt-Peterburg: Izd-vo SPbGPU [in Russian].

Hanson, E. C. (2017) A history of international communication studies. Oxford Research Encyclopedia of International Studies. https://doi.org/10.1093/acrefore/9780190846626.013.63.

Kislov, D.V. (2012). Suchasni media ta informatsiini viiny: monohrafiia [Modern media and information warfare mongography]. Kyiv: «MP Lesya» [in Ukrainian].

Kuznetsov, M. M. (2011). Opyit kommunikatsii $v$ informatsionnuyu epohu. Issledovatelskie strategii Adorno T. V. i M. Maklyuena [Communication experience in the information age. Research Strategies by T. V. Adorno and M. McLuhan]. Moscow: IFRAN [in Russian].

Lasswell, H. (1942). Analysing the content of mass communication: A brief introduction, Prentice-Hall, N. Y. 10(1), pp. 3-8

Shalina, I. V., (2016). Sovremennaya kommunikativistika: praktikum [Modern communication science: practical]. Ural University Publishing House, Ekaterinburg [in Russian].

Sorokin, P. A., (1992). Chelovek. Tsivilizatsiya. Obschestvo [Human. Civilization. Society]. Moscow: Politizdat [in Russian].

Veber, M. (1990). Protestantskaya etika i duh kapitalizma [Protestant ethics and the spirit of capitalism]. Izbrannyye proizvedeniya. Moscow: Progress [in Russian].

\section{Кіслов Денис Васильович}

Інститут журналістики, кіно і телебачення, Київського міжнародного університету 49, вул. Львівська, м. Київ, Україна, 03179

\section{Становлення наукових досліджень в контексті комунікології 1920-1930 pp.}

Анотація. У статті розглядається $і$ аналізується очінка ролі $і$ значення комунікації в державних системах управління в праџях $i$ висловлюваннях 
видатних представників політичної думки від античності до початку ХХстоліття, відповідно до розуміння суті даного явища в розглянуті історичні епохи. Показано, щуо з історї політичної думки хоч $і$ відомі деякі досить обгрунтовані концепиії взаємин влади $i$ населення мислителів стародавнього Китаю, Індіi $i$ античності, але вони вимагають більш детального та систематизованого осмислення. Послідовно розглянуто вплив управлінсько-комунікативних ідей Конфуція, Платона $i$ Аристотеля на наступні праці Цезаря, Цицерона, мислителів Середніх віків, епох Відродження i Просвітництва. Проведено порівняльний аналіз окремих поглядів на взасмозв'язок стану державного управління $і$ комунікачї теологів $і$ вчених XIIIХVIII століть: Ф.Аквінського, Ф. Петрарки, Л. Бруні, Н. Макіавеллі, М. Лютера, Т. Мора, Т. Кампанелли, Ж. Бодена, Г.Гроиія, Дюс. Локка, Т. Гоббса. Особливу увагу приділено ідеям Ш. Монтеск'є, І. Канта і Г.-В.Ф. Гегеля як основоположників наукового дискурсу навколо проблем війни $i$ миру, ефективності державного управління та взаємовідносин з суб'єктами цьього управління, з народом. Зокрема, розглянуто і напрацювання Чиказької школи в США та Інституту соціальних досліджень у Німеччині якими було закладено теоретичний фундамент в початок формування теорій інформації та комунікації, які створили основу сучасного етапу розвитку комунікативістики в кінизі XX століття - на початку XXI століття. Дослідження і аналіз в роботі перших історичних ідей і теоретичних концепџій ролі, місия та значення комунікації в системах державного управління, висунутих протягом 2500 років плеядою видатних мислителів минулого дозволяє переосмислити джерела концептуальних положень комунікативістики, висунуті в ХX столітті, i підійти до об'єктивної оцінки перспективної ролі комунікаційної складової цүивілізаціийного розвитку людства в XXI столітті.

Ключові слова: історія науки; історія вивчення комунікаџїі; комунікаџійні дослідження; комунікація; комунікабельність; теорія комунікації

\section{Кислов Денис Васильевич}

Институт журналистики, кино и телевидения

Киевского международного университета

49, ул. Львовская, г. Киев, Украина, 03179

\section{Становление научных исследований в контексте коммуникологии 1920-1930 гг.}

Аннотация. В статье рассматривается и анализируется оценка роли и значения коммуникации в государственных системах управления в трудах $u$ высказываниях выдающихся представителей политической мысли от античности до начала XX века в соответствии с пониманием сути данного явления в рассматриваемые исторические эпохи. Показано, что из истории 
политической мысли хоть и известны некоторые достаточно обоснованные концеепции взаимоотношений власти и населения мыслителей древнего Китая, Индии и античности, но они требуют более детального $u$ систематизированного осмысления. Последовательно рассмотрено влияние управленческо-коммуникативных идей Конфуциия, Платона и Аристотеля на последуюшие труды Цезаря, Цицерона, мыслителей Средних веков, эпох Возрождения и Просвещзения. Проведен сравнительный анализ отдельных взглядов на взаимосвязь состояния государственного управления $u$ коммуникации теологов и ученых XIII-XVIII веков: Ф. Аквинского, Ф. Петрарки, Л. Бруни, Н. Макиавелли, М. Лютера, Т. Мора, Т. Кампанелль, Ж. Бодена, Г. Грочия, Дю. Локка, Т. Гоббса. Особое внимание уделено идеям Ш. Монтескье, И. Канта и Г.-В.-Ф. Гегеля как основоположников научного дискурса вокруг проблем войны и мира, эффективности государственного управления и взаимоотношений с субъектами этого управления, с народом. $B$ частности, рассмотрено и наработки Чикагской школьг в США и Института социиальных исследований в Германии которыми было заложено теоретический фундамент в начало формирования теорий информации и коммуникации, создавиих основу современного этапа развития коммуникативистики в конце XX века-начале XXI века. Исследование и анализ в работе первых исторических идей и теоретических концеепций роли, места и значения коммуникации в системах государственного управления, выльинутых на протяжении 2500 лет плеядой выдающихся мыслителей прошлого позволяет переосмыслить источники концептуальных положений коммуникативистики, выдвинутые в ХХ веке, и подойти к объективной оченке перспективной роли коммуникационной составляющей цүивилизационного развития человечества в XXI веке.

Ключевые слова: история науки; история изучения коммуникации; коммуникационные исследования; коммуникация; коммуникабельность; теория коммуникации

Received 15.03.2019

Received in revised form 05.05.2019

Accepted 24.05.2019 